\title{
Yeasts and Filamentous Fungi in Bottled Mineral Water and Tap Water from Municipal Supplies
}

\author{
Mirian Ueda Yamaguchi ${ }^{1}$, Rita de Cássia Pontello Rampazzo ${ }^{2}$, Sueli Fumie Yamada- \\ Ogatta $^{2}$, Celso Vataru Nakamura ${ }^{3}$, Tânia Ueda-Nakamura ${ }^{3}$ and Benedito Prado Dias \\ Filho $^{3 *}$ \\ ${ }^{1}$ Programa de Pós-Graduação em Análises Clínicas; Universidade Estadual de Maringá; Av. Colombo, 5790; \\ 87020-900; Maringá - PR - Brasil. ${ }^{2}$ Departamento de Microbiologia; Universidade Estadual de Londrina; Rodovia \\ Celso Garcia Cid, PR 445; 86051-990; Londrina - PR - Brasil. ${ }^{3}$ Departamento de Análises Clínicas; Universidade \\ Estadual de Maringá; Av. Colombo, 5790; 87020-900; Maringá - PR - Brasil
}

\begin{abstract}
The main objective of this study was to analyse the occurrence of yeasts and filamentous fungi in drinking water as well as to investigate their correlation with the indicator bacteria of faecal pollution. Yeasts were detected in $36.6 \%$ and $11.6 \%$ of the bottled mineral on water dispensers and tap water samples from municipal system, respectively. Twenty-one (35.0\%) of bottled mineral water and two (3.3\%) of tap water samples were positive for filamentous fungi. For bottled mineral water 12 (20.0\%) of 60 samples were positive for total coliform, compared with 3(5.0\%)out of 60 samples from tap water. The mineral water from dispensers was more contaminated than tap water. Strains belonging to the genera Candida identified to the species level were C. parapsilosis, C. glabrata and C. albicans. Thus, bottled mineral water from water dispensers and tap water could be considered a possible transmission route for filamentous fungi and yeasts, and could constitute a potential health hazard, mainly to immunocompromised indivuals.
\end{abstract}

Key words: Candida, filamentous fungi, bottled mineral water, tap water, indicator bacteria

\section{INTRODUTION}

Fungi are widely distributed in nature and can occur as unicellular yeast or filamentous and, multicellular molds. There are over 70,000 species of fungi. Fewer than 300 have been implicated in human diseases, and fewer than a dozen cause about $90 \%$ of all fungus infections. They are involved in different forms of diseases, including allergies to fungal antigens, production of toxins, or direct invasion of hosts (McGinnis, 1996).

Several species of fungi are capable of infecting healthy hosts and causing diseases ranging from mucosal to life-threatening disseminated infections. In addition, there are an increasingly number of severe fungal diseases by commensal or fully saprophytic species in immunocompromised hosts. These diseases are frequently associated with abrogated host immunity as a result of viral infections, mainly the human immunodeficiency virus, hematological and hormonal disorders, organ transplants, antibiotic usage, and more intensive and agressive medicals practices (van Burik and Magee, 2001). Fungal infections are difficult to treat since the agents are eukaryotes, as human cells. Despite their wide occurrence, little

\footnotetext{
* Author for correspondence
} 
attention has been given to their presence and significance in aquatic environments (Souza et al., 2003). Drinking water distribution systems are colonized by saprophytic heterotrophic microorganisms (such as bacteria, fungi, yeast) that grow on biodegradable organic matter (Servais et al., 1992). However, potentially pathogenic microorganism and microorganisms of faecal origin can also find favorable condition and proliferate in these systems (Petrucio et al., 2005). The quantity of bacteria in commercial mineral water is generally dependent of good manufacturing practices and autochthonous flora of the spring. It is well known that natural mineral water is characterized by its bacterial flora, chemical and physical composition. In addition to natural contamination, the product can also be deteriorated before it reaches the consumer (Nsanze and Babarinde, 1999).

The Brazilian directives (ANVISA, 2000; 2004) regulate water from municipal water supplies on the basis of coliform content and heterotrophic plate count, whereas more stringent bottled mineral water regulations prohibit the presence of a group of potentially pathogenic bacteria (Pseudomonas, faecal Streptococci and Clostridia). Although microbiological standards exist for bottled water, the same product once installed on a dispenser is generally not regulated and is rarely controlled.

In the present study, total and faecal coliform, and total heterotrophic bacteria were estimated in parallel with countig of yeasts and filamentous fungi in 201 bottles of water dispensers and municipal tap water. The main objective of this study was to analyse the occurrence of yeasts and filamentous fungi in drinking water as well as to investigate their correlation with the indicator bacteria of faecal pollution. In addition, Candida strains from different sources were identified by morphological and molecular methods.

\section{MATERIALS AND METHODS}

\section{Water samples}

Residences and workplaces were randomly selected from the list of the Companhia de Saneamento do Paraná of the Maringá city, Paraná State, Brazil. The common criteria for sampling place considered in this study was the presence of water dispensers with a 201 bottle mineral water supplied by a recognized company. In Brazil, natural mineral water is an extremely specific product, characterized by a constant level of minerals and trace elements. This water cannot be treated, nor added any exogenous elements. Then, 30 residences and 30 workplaces served by municipal water system were selected. The samples for microbiological analysis were collected in sterilized plastic bottles with sodium thiosulfate (10\% w/v, Merck, São Paulo, Brazil) and transported to the laboratory in ice. Analyses were carried out within $4 \mathrm{~h}$ of sampling.

\section{Microbial enumeration}

To assess water quality, samples were analyzed for total coliforms (TC) using a multiple-tube fermentation technique (Clesceri et al., 1998) based on lactose fermentation with production of acid and gas within $48 \mathrm{~h}$ in a lauryl tryptose broth (Difco, Maryland, USA). If the water sample yielded presumptively positive results, simultaneous inoculation into brilliant green lactose bile broth (Difco, Maryland, USA) for total coliforms and EC broth (Difco, Maryland, USA) for faecal coliforms (FC) was required. Cellular growth for EC broth incubated at $44.5^{\circ} \mathrm{C}$ for $24 \mathrm{~h}$, were considered as positive complete test. Parallel positive brilliant green lactose bile broth with negative EC broth cultures indicated the presence of nonfecal coliforms.

The membrane filter technique was employed for yeasts and fungi (Clesceri et al., 1998). A volume of $100 \mathrm{ml}$ of the samples was filtered through membrane filters with $0.45 \mu \mathrm{m}$ pores (Millipore, Massachusettes, USA). The membranes were placed on Sabouraud dextrose agar (SDA, Difco, Maryland, USA) supplemented with streptomycin $(50 \mu \mathrm{g} / \mathrm{ml})$. The plates were incubated at room conditions of temperature $\left(20\right.$ to $\left.24{ }^{\circ} \mathrm{C}\right)$ and examined daily during one week. The pour plate method (Clesceri et al., 1998) was used to estimate the number of heterotrophic bacteria in plate count agar (Oxoid, Hampshire, England), at $37{ }^{\circ} \mathrm{C}$, for $48 \mathrm{~h}$.

\section{Isolation and identification of yeasts}

Colonies on SDA were subcultured in the same medium to isolate a pure, single colony for identification tests. Each isolate was examined by Gram stain and germ-tube test in the presence of serum for preliminar identification of yeasts. The polymerase chain reaction (PCR) based method for species identification was performed using 
oligonucleotide primers directed against 3' end of $5.8 \mathrm{~S}$ and 5 ' end of $28 \mathrm{~S}$ rDNA region, as described by Ahmad et al., 2002. According to this method the first PCR round is carried out with universal oligonucleotide primers for detection of Candida sp (forward primer CTSF 5'TCGCATCGATGAAGAACG CAGC- 3 ' and reverse primer CTSR TCTTTTCCTCCGCTTATTGATATGC-3'). The product of this amplification cycle is submitted to a second reaction using CTSR and species-specific oligonucleotide primers of Candida albicans (CADET, 5'- ATTGCTTGCGGCGGTAAC GTCC-3'), C. parapsilosis (CPDET, 5'ACAAACTCCAAAACTTCTTCCA-3'), $\quad C$. tropicalis (CTDET, 5, -AACGCTTTATTT TGCTAGTGGCC-3'), and C. glabrata (CGDET, 5'-TAGGTTTTACCAACTCGT GTT -3').
Genomic DNA extraction was performed according to Ausubel et al, (1999) with certain modifications on method as described in Jain et al, 2001.

\section{Statistical analysis}

Results were analyzed by linear regression and $t$ test, at $p<0.05$ and 0.005 of confidence level.

\section{RESULTS}

\section{Microbial enumeration}

The results of microbiological analyses performed on samples from the 20-L bottles water on water dispenser and tap water from municipal supplies are showed in Table 1.

Table 1 - Yeasts, filamentous fungi, total coliform and faecal coliform in samples collected from bottled mineral water and tap water from municipal supplies.

\begin{tabular}{|c|c|c|}
\hline \multirow[b]{2}{*}{ Microorganism } & \multicolumn{2}{|c|}{ Number of positive samples (percentage) } \\
\hline & Bottled mineral water ${ }^{\mathrm{a}}(\mathrm{n}=60)$ & Tap water ${ }^{b}(n=60)$ \\
\hline Yeasts & $22(36.6)$ & $7(11.6)$ \\
\hline Filamentous fungi & $21(35.0)$ & $2(3.3)$ \\
\hline Total coliform & $12(20.0)$ & $3(5.0)$ \\
\hline Faecal coliform & 0 & 0 \\
\hline
\end{tabular}

${ }^{\mathrm{a}} 201$ bottles; ${ }^{\mathrm{b}}$ Most-often-used faucet

Twenty one $(35.0 \%)$ samples with heterotrophic plate count (HPC) over the maximum level legally permitted in Brazil (500 colony forming units $/ \mathrm{ml}$ ) were bottled mineral water from water dispensers. Of the 60 tap water samples from municipal supplies, none had bacterial count over $500 \mathrm{cfu} / \mathrm{ml}$ (Table 2). None of the 120 samples was found to contain faecal coliform.

The mean, maximum and minimum colony forming units (cfu) of filamentous fungi and yeasts in bottled mineral water and tap water samples are shown in Table 3. A significant difference in the counts of filamentous fungi and yeasts was observed between samples from bottled mineral and tap water. The mean of $\mathrm{cfu} / \mathrm{ml}$ of both filamentous fungi and yeasts was significantly higher in mineral water than in tap water.
Spearman rank correlation was established to compare the degree of association between fungi and the contamination indicator bacteria in bottled mineral and tap water (Table 4). When correlations were separately tested for bottled mineral water samples a significant positive correlation among yeasts and total heterotrophic bacteria was found, while filamentous fungi were positively correlated with total coliform and total heterotrophic bacteria. The presence of yeasts, in bottled mineral water samples was not correlated with filamentous fungi and total coliform.

In tap water samples yeasts were significantly correlated with filamentous fungi and total heterotrophic bacteria, while filamentous fungi were not correlated with the presence of total coliform. 
Table 2 - Heterotrophic plate counts (HPC) in bottled mineral water and tap water

\begin{tabular}{c|cc}
\hline \multirow{2}{*}{ HPC } & \multicolumn{2}{|c}{ Number (percentage) } \\
\cline { 2 - 3 } & $\begin{array}{c}\text { Bottled mineral water } \\
(\mathrm{n}=60)\end{array}$ & $\begin{array}{c}\text { Tap water } \\
(\mathrm{n}=60)\end{array}$ \\
\hline$<50$ & $15(25.00)$ & $56(93.33)$ \\
$50-500$ & $24(40.00)$ & $4(6.67)$ \\
$>500$ & $21(35.00)$ & $0(0.00)$ \\
& & $0-300$ \\
Range & $0-30000$ & 14.00 \\
Median & 1693.35 & \\
\hline
\end{tabular}

$\mathrm{cfu} / \mathrm{ml}$

$\underline{\text { Table } 3 \text { - Enumeration of yeasts and filamentous fungi in positive bottled water and tap water samples. }}$

\begin{tabular}{lcccc}
\hline & & \multicolumn{3}{c}{ Colony forming units/ml } \\
\cline { 3 - 4 } Microorganism & No. & Minimum & Maximum & Mean \\
\hline Bottled Mineral water & & & 100 & 10.8 \\
$\begin{array}{l}\text { Yeasts } \\
\text { Filamentous fungi }\end{array}$ & 21 & 1 & 50 & 11.6 \\
Tap water & & & & 2.8 \\
Yeasts & 7 & 1 & 1 & 1.0 \\
Filamentous fungi & 2 & 1 & & \\
\hline
\end{tabular}

Table 4 - Spearman correlation coefficients among bacteria indicator, yeasts and filamentous fungi

\begin{tabular}{|c|c|c|c|c|c|c|}
\hline \multirow{2}{*}{ Microorganism } & \multicolumn{6}{|c|}{ Correlation coefficient } \\
\hline & \multicolumn{3}{|c|}{ Mineral water ${ }^{a}$} & \multicolumn{3}{|c|}{ Tap water ${ }^{b}$} \\
\hline Yeasts & $0.26 *$ & & & - & & \\
\hline Filamentous fungi & $0.34 *$ & 0.08 & & - & $0.33 *$ & \\
\hline Total coliform & $\begin{array}{c}0.40 * * \\
\mathrm{HPC}\end{array}$ & $\begin{array}{l}0.22 \\
\text { Yeasts }\end{array}$ & $\begin{array}{l}\quad 0.27^{*} \\
\text { Filamentous fungi }\end{array}$ & $\begin{array}{c}- \\
\mathrm{HPC}\end{array}$ & $\begin{array}{l}0.36 * * \\
\text { Yeasts }\end{array}$ & $\begin{array}{l}\quad-0.03 \\
\text { Filamentous fungi }\end{array}$ \\
\hline
\end{tabular}

Significance level: $* \mathrm{p}<0.05, * * \mathrm{p}<0.005$

a 20 -litre bottles on water dispensers.

${ }^{\mathrm{b}}$ Most-ofen-used faucet.

Table 5 - Frequency of isolation of yeasts in bottled mineral and tap water

\begin{tabular}{lcc} 
& Yeasts & \multicolumn{2}{c}{ No. of samples } \\
\cline { 2 - 3 } & Bottled mineral & Tap water \\
\hline C. parapsilosis & 10 & 4 \\
C. glabrata & 6 & 1 \\
C. albicans & 0 & 1 \\
Candida spp & 3 & 1 \\
Non-Candida & 1 & 0 \\
\hline
\end{tabular}

\section{Isolation and identification of yeasts}

A total of 27 strains were isolated from SDA incubated at $37^{\circ} \mathrm{C}$. The isolates were identified to species levels by snPCR and the frequency of isolated yeasts is shown in Table 5. Candida spp identified to the species level were C.parapsilosis (fourteen isolates), C.glabrata (seven isolates) and C.albicans (one isolate). Other genus of yeast 
isolated from water samples was not identified (one isolate).

\section{DISCUSSION}

The objective of this study was to determine the frequency and densities of yeasts and filamentous fungi in bottled mineral and tap water, as well as their correlation with the indicator bacteria. The prevalence of fungi was investigated in parallel with the standard indicator microorganisms in 120 drinking water samples from 20 -L bottles mineral on water dispensers and tap water in residences and workplaces.

The Coliform organisms have long been recognized as a suitable microbial indicator of drinking-water quality, largely because they are easy to detect and enumerate in water (WHO, 1993). In drinking water from municipal supplies, the coliform test can be used as an indicator of the treatment efficiency and the integrity of the distribution system. Although coliform organisms may not always be directly associated to the presence of faecal contamination, the presence of coliforms in drinking water suggests the potential presence of pathogenic enteric microorganisms such as Salmonella spp, Shigella spp, and Vibrio cholerae. Coliform bacteria are the only microbiological contamination to be regulated by federal law in both tap and bottled water.

According to the Brazilian directives, at least 40 samples per month of tap water from each public water supply should be analysed and the bacterial indicator must not be present in $95 \%$ of the samples taken throughout any 12-month period. In the case of minimum frequencies, one sample every week for waterworks with surface water source and one sample every two weeks for waterworks with a ground water source the indicator must not be detectable in any $100-\mathrm{ml}$ sample.

None faecal coliform bacteria was found in all samples analysed in this study, suggesting the absence of faecal contamination in these water samples. However, the finding that 20 and $5 \%$ of the bottled water and tap water, respectively, sampled in the current study failed to meet the Brazilian standard for total coliforms in drinking water should therefore, be of concern. These results suggested the need for an improved surveillance system for the bottled water industry.
Based on the Brazilian regulations, disinfection or sterilization of commercially available mineral water is not permitted Therefore, they generally have high heterotrophic plate counts (HPC) a few days after bottling that should result only from an increase of bacteria present in the source water. The number of bacteria recovered at the source is generally very low, around $10 \mathrm{cfu} / \mathrm{ml}$, but there are many reports that viable counts increase, notably in uncarbonated water, to $10^{4}-10^{5} \mathrm{cfu} / \mathrm{ml}$ after $1-2$ weeks of storage (Tamagnini and Gonzales, 1997; Bischofberger et al., 1990; Mavridou, 1992; Mavridou et al., 1994; Tsai and Yu, 1997).

The number of samples with heterotrophic plate count over the maximum level legally permitted in Brazil $(500 \mathrm{cfu} / \mathrm{ml})$ was $21(35.0 \%)$ of samples from bottled mineral water. Heterotrophic plate count ranged from $0-30000 \mathrm{cfu} / \mathrm{ml}$ among the 60 bottles water examined, including 39 samples with levels above $500 \mathrm{cfu} / \mathrm{ml}$. Of the 60 tap water samples from municipal supply, none had bacterial count above $500 \mathrm{cfu} / \mathrm{ml}$. Considering that heterotrophic plate count is indicator of hygienic conditions and the disinfection do no eliminate completely these bacteria, different ranges of total bacterial densities could be achieved

The recovery of yeasts was significantly higher in bottled mineral water than in tap water from municipal supplies.

The mean number of $\mathrm{cfu} / \mathrm{ml}$ was 10.8 and 11.6 for yeasts and filamentous fungi in bottled mineral water, respectively. In municipal tap water, the mean number of cfu/ml was 2.8 for yeasts and 1.0 for filamentous fungi. However, it should be mentioned that quantitative enumeration of fungi is not equivalent to that of unicellular organisms because a fungal colony may be formed of a single cell or aggregate of cells or from a mycelial fragments.

A correlation coefficient matrix was established to compare the degree of association between fungi and the contamination indicator bacteria. Different results were observed with samples from bottled mineral and tap water from municipal supply. The occurrence of the yeasts did not correlate significantly with traditionally used contamination indicator bacteria (i.e. total coliform) in bottled mineral water samples. The lack of correlation between yeasts and total coliform suggested that the two microorganisms could indicate different source of pollution. However, a significant correlation was found between yeasts and total coliform in tap water samples. The presence or 
absence of a correlation between indicator bacteria and fungi could reflect the occasional appearance of pathogens in drinking water and the different rates of survival and recovery of these agents compared with those faecal indicators.

Finally, results showed that Candida spp was the most prevalent yeast isolates from the water samples. C.parapsilosis was the predominant yeast identified, followed by $C$. glabrata and $C$. albicans. For some yeasts, it was impossible identify to the species level with the tests used in this study. Candida spp was assigned based on seminested-PCR method (Ahmad et al., 2002), which used CTSF and CTSR universal oligonucleotide primers at the first PCR round to identify yeast genera.

The incidence of nosocomial infections caused by Candida strains has risen with change of the implicated species and risk factors predisposing to Candidaemia, including multiple antibiotic therapy, colonization with Candida of sites other than blood. The ability of $C$. albicans to colonize the host epithelium is important to establish an infection in the host (Calderone and Braun, 1991). By 1963, approximately, five medically important species of Candida have been described. The species were $C$. albicans, $C$. stellatoides ( now considered synonymous with $C$. albicans), $C$. parapsilosis, C. tropicalis and C. guillhermondii (Wickes et al., 1992). However, the advent in the 1960s of new modalities of cancer's treatment, use of central venous catheters, an explosion in new antibacterial agents, increasing in average life expectancy, and other developments in medicine soon paved the way for innocuous yeasts to cause serious infections. There are now at least 17 species of Candida that have been shown to cause diseases in human (Elie et al., 1998) and the list of yeast that can cause diseases are rising. Although C. parapsilosis is described as a harmless commensal of the normal human microflora on skin surfaces (Mok and Barreto, 1984), it is also an important pathogen commonly isolated from pathological lesions of the nails and skin (Weems, 1992). Furthermore, this species has recently emerged as an important nosocomial pathogen (Huang et al., 2000). Fungemia due to $C$. parapsilosis has generally been related to the presence of central venous catheter, as well as to the parental nutrition (Girmenia et al., 1996). Unlike other Candida species, C. parapsilosis causes nosocomial candidemia without prior colonization in other sites, suggesting that this yeast might gain access to the bloodstream directly from environmental sources (Levin et al., 1998). Characteristics of $C$. parapsilosis that may be associated to its increasing occurrence in nosocomial setting include frequent colonization of the skin, particularly the subungual space, and an ability to proliferate in glucose-containing solutions, with a increase in adherence to synthetic materials (Weems, 1992).

In recent years, an increase in the prevalence of $C$. glabrata isolates with reduced susceptibilities to triazole antifungals have heightened concerns regarding the empirical use of triazole-based drugs, especially in patients at risk of systemic invasion (Abi-Said et al. 1997; Viscoli et al. 1999; Wingard et al. 1993). Actually, depending on the site of infection, C. glabrata is often the second or third most common cause of candidiasis after $C$. albicans (Wingard, 1995). In contrast to other Candida species, C. glabrata is not dimorphic, consequently, it is found as blastoconidia both as a commensal and as a pathogen. C. glabrata infections are difficult to treat and are often resistant to many azole antifungal agents, especially fluconazole. Consequently, $C$. glabrata infections have a high mortality rate in compromised, at-risk hospitalized patients. However, there have been relatively few investigations of $C$. glabrata compared to other Candida species.

There are few reports in the literature regarding the occurrence of yeasts and filamentous fungi in treated water and bottled mineral water. This is due, in part, to the fact that causal relationships between fungal occurrence and water quality remain uncertain. Previous studies have reported the characterization of fungal biofilms within municipal water distribution systems. Densities of filamentous fungi ranged from 4.0 to $25.2 \mathrm{cfu} / \mathrm{cm}^{2}$, whereas yeast densities ranged from 0 to 8.9 $\mathrm{cfu} / \mathrm{cm}^{2}$. Observations by scanning electron microscopy further suggested that spores, not hyphae or vegetative cells, comprised the primary source of viable propagules (Doggett, 2000). The prevalence of fungi was investigated in potable water from hospital and community samples (Arvanitidou et al., 1999). Filamentous fungi were isolated from $82.5 \%$ samples and yeasts from $11.1 \%$, and the prevailing genera were Penicilium spp., Aspergillus spp. and Candida spp. Recently, Arvanitidou et al., (2000) have reported the recovery of fungi from water and dialysate in haemodialysis units. In this study, filamentous 
fungi and yeasts were isolated from 69 and from 3 feed water samples, from 74 and 7 samples of treated water and from 66 and 11 dialysate samples respectively. Aspergillus spp and Penicillium spp were the most frequent molds, while Candida spp were the prevailing yeasts. Filamentous fungi were recovered from $94 \%$ of all the water samples taken from a paediatric bone marrow transplantation unit (Warris et al., 2001). A.fumigatus was recovered from $49 \%$ and $5.6 \%$ of water samples from the taps and showers, respectively.

More recently, Cabral and Pinto (2002) reported the occurrence of filamentous fungi together with bacteriological parameters in 126 samples of still bottled mineral water of eight different commercial brands in Argentina. In spoiled samples with visible mycelium growth, the most frequently isolated fungal species were Penicillium citrinum, P. glabrum, other Penicillium species, Cladosporium cladosporioides and Alternaria alternata. In unspoiled samples, the genera found were Penicillium, Cladosporium, Rhizopus, Aspergillus and Phoma. In this study, only three of the 126 samples failed to meet the required microbiological standards because they were found to contain faecal streptococci.

In the present study, the water from bottled mineral water from was more contaminated than tap water. Candida spp identified to the species level were $C$. parapsilosis, $C$. glabrata and $C$. albicans.

Thus, bottled mineral water from water dispensers and tap water in residence and workplace could be considered a possible transmission route for filamentous fungi and yeasts. However, investigation of the virulence factors of the isolated yeasts is essential because they may constitute a potential health hazard, mainly to immunocompromissed individuals. In addition, these results could contribute to the re-evaluation of the criteria used to analyse the microbial quality of drinking water since yeasts and filamentous fungi were detected in samples, in which, total and faecal coliforms were not detected.

\section{ACKNOWLEDGEMENTS}

This work was supported by the Conselho Nacional de Desenvolvimento Científico e Tecnológico (CNPq), Financiadora de Estudos e Projetos (FINEP), Coordenação de
Aperfeiçoamento de Pessoal de Nível Superior (CAPES), Fundação Araucária, and Programa de Pós-graduação em Análises Clínicas da Universidade Estadual de Maringá.

\section{RESUMO}

O principal objetivo do presente estudo foi avaliar a prevalência de leveduras e fungos filamentosos em água potável, bem como investigar suas correlações com bactérias indicadoras de contaminação fecal. Leveduras foram detectadas em $36,6 \%$ e $11,6 \%$ das amostras de água mineral de garrafão em dispensadores de água e água de torneira do sistema municipal, respectivamente. Vinte e uma $(35,5 \%)$ das amostras de água mineral de garrafão e duas $(3,3 \%)$ das amostras de água de torneira foram positivas para fungos filamentosos. Para água mineral de garrafão, $12(20.0 \%)$ das 60 amostras foram positivas para coliforme total, comparado com 3 (5.0\%) das 60 amostras de água de torneira. A água coletada de garrafões de água mineral dos dispensadores foi marcadamente mais contaminada que as amostras de água de torneira. Candida spp identificadas ao nível de espécie foram C. parapsilosis, C. glabrata e C. albicans. Como está sendo reportado, água mineral de garrafão em dispensador e água de torneira pode ser considerada como possíveis vias de transmissão de fungos filamentosos e leveduras, e podem constituir um potencial risco para a saúde, principalmente de pessoas imunocomprometidas.

\section{REFERENCES}

Abi-Said, D.; Anaissie, E.; Uzun, O.; Raad, I.; Pinzcowski, H. and Vartirarian, S. (1997), The Epidemiology of hematogenous candidiasis caused by different Candida species. Clin. Infect. Dis., 24 : (6), 1122-1128.

Agência Nacional de Vigilância Sanitária (ANVISA) (2000), Normas e padrão de potabilidade da água destinada ao consumo humano. RDC 54, 15/06/2000. Available at: http://e-legis.bvs.br/leisref/public/ search.php.

Agência Nacional de Vigilância Sanitária (ANVISA) (2004), Identidade e qualidade de água mineral natural e água natural. Portaria 518, 25/03/2004. Available at: http://e-legis.bvs.br/leisref/public/ search.php. 
Ahmad, S.; Khan, Z.; Mustafa, A. S. and Khan, Z. U. (2002), Seminested PCR for diagnosis of candidemia: Comparison with culture, antigen detection, and biochemical methods for species identification. $J$. Clin. Microbiol., 40, 2883-2489.

Arvanitidou, M.; Kanellou, K.; Constantinides, T. C. and Katsouyannpoulos, V. (1999), The occurrence of fungi in hospital and community potable waters. Letters in Applied Microbiology, 29, 81-84.

Arvanitidou, M.; Spaia, S.; Velegrak, A.; Pazarloglou, M.; Kanetidis, D.; Pangidis, P.; Askepidis, N.; Katsinas, C. H.; Vayonas, G. and Katsouyannopoulos, V. (2000), High level of recovery of fungi from water and dialysate in haemodialysis units. J. Hosp. Infect., 45, 225-230.

Ausubel, F. M.; Brent, R.; Kingston, R. E.; Moore, D. D.; Seidman, J. G.; Smith, J. A. and Struhl, K. (1999), Short protocols in molecular biology. $4^{\text {th }} \mathrm{ed}$. New York: John Wiley and Sons.

Bischofberger, T.; Cha, S. K.; Schmitt, R.; Konig, B. and Schmidt-Lorenz, W. (1990), The bacterial flora of non-carbonated, natural mineral water from springs to reservoir and glass and plastic bottles. International Journal of Food Microbiology, 11, 51-72.

Cabral, D. and Pinto, V. E. F. (2002), Fungal spoilage of bottled mineral water. Int. J. Food Microbiol., 72, 73-76.

Calderone, R. A. and Braun, P. C. (1991), Adherence and receptor relationships of Candida albicans. Microbiol Rev., 55, 1-20.

Clesceri, L. S.; Greenberg A. S. and Eaton, A. D. (1998), Standard methods for the examination of water and wastewater. $20^{\text {th }}$ ed. American Public Health Associtation (APHA).

Doggett, M. S. (2000), Characterization of fungal biofilm within a municipal water distribution system. Appl Environ Microbiol, 66, 1249-1251.

Elie, C. M.; Lott, T. J.; Reiss, E. and Morrison, C. J. (1998), Rapid Identification of Candida Species with Species-Specific DNA Probes. J. Clin. Microbiol., 36, 3260-3265.

Girmenia, C.; Martino, P.; De Bernardis, F.; Gentile, G.; Boccanera, M.; Mônaco, M.; Antonucci, G. and Cassone, A. (1996), Rising incidence of Candida Parapsilosis fungemia in patients with hematologic malignancies: clinical aspectis, predidsposin factors, and differential pathogenicity of causative strains. Clin Infect Dis., 23 : (3), 506-514.

Huang, Y. C.; Lin, T. Y.; Lien, R. I.; Chou, Y. H.; Kuo, C. Y.; Yang, P. H. and Hsieh, W. S. (2000), Candidaemia in special care nurseries: comparison if albicans and parapsiolosis infecation. J. Infect., 40, 171-175.
Jain, P.; Khan, Z. K.; Bhattacharya, E. and Ranade, S. A. (2001), Variation in random amplified polymorphic DNA (RAPD) profiles specific to fluconazole-resistant and -sensitive strains of Candida albicans. Diag. Microbiol. Infect. Dis., 41, 113-119.

Levin, A. S.; Costa, S. F.; Mussi, N. S.; Basso, M.; Sinto, S. I.; Machado, C.; Geiger, D. C.; Villares, M. C. B.; Schreiber, A. Z.; Barone, A. A. and Branchini, M. L. M. (1998), Candida parapsilosis fungemia associated with implantable and semi-implantable central venous catheters and the hands of healthcare workers. Diagn. Microbiol. Infect. Dis., 30, 243-249.

McGinnis, M. R. (1996), Micology. In: Baron, S. (Ed.). Medical Microbiology. $4^{\text {th }}$ ed. Texas: Galveston.

Mavridou, A. (1992), Study of the bacterial flora of a non-carbonated natural mineral water. J. Appl. Bacteriol., 73, 355-361.

Mavridou, A.; Papapetropoulou, M.; Boufa, P. et al. (1994), Microbiological quality of bottled water in Greece. Lett. Appl. Microbiol., 19, 213-216.

Mok, W. Y. and Barreto, M. S. S. (1984), Mycoflora of the human dermal surfaces. Can. J. Microbiol., 30, 1205-1209.

Petrucio, M. M.; Medeiros, A. O.; Rosa, C. A. and Barbosa, F. A. R. B. (2005), Trophic state and microorganisms community of major sub-basins of midle Rio Doce Basin, Southeast Brasil. Brazilian Archives of Biology and Technology, 48, 625-633.

Nsanze, H. and Babarinde, Z. (1999), Microbiological quality of bottled drinking water in the UAE and the effect of storage at different temperatures. Envirnon. Internal, 25, 53-57.

Servais, P.; Billen, G.; Laurent, P.; Lévi, Y. and Randon, G. (1992), Studies of BDOC and bacterial dynamics in the drinking water distribution systems of the Northern Parisian suburds. Revue des Sciences de l'Eau, 5, 69-89.

Souza, A. D. G. and Tundisi, J. G. (2003), Water quality in watershed of Jaboatão River (Pernambuco, Brazil): a case study. Brazilian Archives of Biology and Technology, 46, 711-721.

Tamagnini, L. M. and Gonzalez, R. D. (1997), Bacteriological stability and growth kinetics of Pseudomonas aeruginosa in bottled water. Journal of Applied Microbiology, 83, 91-94.

Tsai, G. and Yu, S. C. (1997), Microbiological evaluation of bottled uncarbonated mineral water in Taiwan. International Journal of Food Microbiology, 37, 137-143.

Van Burik, J. A. and Magee, P. T. (2001), Aspects od fungal pathogenesis en humans. Ann. Rev. Microbiol., 55, 743-772. 
Viscoli, C.; Girmenia, C.; Marinus, A.; Collette, L.; Martino, P.; Vandercam, B.; Doyen, C.; Lebeau, B.; Spence, D.; Krcmary, V.; De Pauw, B. and Meunier, F. (1999), Candidemia in cancer patients: a prospective, multicenter surveillance study by the Invasive Fungal Infection Group (IFIG) of the European Organization for Research and Treatment of Cancer (EORTC). Clin. Infect. Dis., 28, 1071-1979.

Warris, A.; Gaustad, P.; Meis, J. F. G. M.; Voss, A.; Verweij, P. E. and Abrahamsen, T. G. (2001), Recovery of filamentous fungi from water in a paediatric bone marrow transplantation unit. Journal of Hospital Infection., 47, 143-148.

Weems Jr., J. J. (1992), Candida parapsilosis: epidemiology pathogenicity, clinical manisfestations, and antiamicrobial susceptibility. Clin. Infec. Disease, 14, 756-766.

Wickes, B. L.; Hicks, J. B.; Merz, W. G. and KwonChung (1992), The molecular analysis of synonymy among medically important yeasts within the genus Candida. J. Gen. Microbiol., 138, 901-907.

Wingard, J. R. (1995), Importance of Candida species other than $C$. albicans as pathogens in oncology patients. Clin.Infect.Dis., 20, 115-125.

Wingard, J. R.; Merz, W. G.; Rinaldi, M. G.; Miller, C. B.; Karp, J. E. and Saral R. (1993), Association of Torulopsis glabrata infections with fluconazole prophylaxis in neutropenic bone marrow transplant patients. Antimicrob. Agents Chemother., 37, 18471849.

World Health Organization - WHO (1993), Guidelines for drinking-water quality. 2. ed. Geneva. Available at: http://www.who.int/water_sanitation_health/.

Received: May 04, 2005; Revised: August 18, 2005; Accepted: November 06, 2006. 


\section{FOLHA}

EM

BRANCO 